\title{
Greek Debt Sustainability and Official Crisis Lending
}

\begin{abstract}
The International Monetary Fund and the European Stability Mechanism softened their crisis lending policies repeatedly to deal with the Greek debt crisis, but the analysis of debt sustainability still acts as the gatekeeper for access to official financing. We explore the underlying mechanics of debt sustainability analysis and show that the standard model is inappropriate for Greece since it ignores the highly concessional terms of Greek debt. Greek debt has been restructured repeatedly, and now two-thirds of the stock contains grant elements of about 54 percent. The present value of outstanding Greek debt is currently about 100 percent of GDP and will rise to about 120 percent under the new program. Greek debt sustainability therefore is less a problem of the debt stock. By simulating different paths of the gross financing needs, we show that there may be liquidity problems over the medium to long terms (in particular, in 2035 and beyond). However, our estimation of the financing need is subject to high uncertainty and mainly depends on whether Greece will be able to regain access to markets at reasonable terms.
\end{abstract}

any people hold strong views on Greek debt. Just taking a casual look at the level of Greece's debt, which the International Monetary Fund (IMF) has recently projected to rise to 200 percent of GDP, it seems obvious that Greek public finances cannot possibly be sustainable (IMF $2015 a, 2015 b)$. What is not obvious is how this can be subject to dispute among the main creditor institutions. Greek official sector debt sustainability assessments have been quite volatile, but by the beginning of 2015 the verdict of the main official creditor institutions-hereafter referred to as the troika for short—was that Greek debt was sustainable. ${ }^{1}$ Eight months

* The author is currently on leave from Johannes Gutenberg University Mainz.

1. The troika consists of the European Central Bank, the European Commission, and the International Monetary Fund. 
later, however, at the time of this writing, the troika has split over the question of debt sustainability; while the Europeans are pushing ahead with a new program for Greece, the IMF is holding out. It seems that the diagnosis of debt sustainability is not so obvious after all.

One reason that a diagnosis of debt sustainability is complicated could be that politics plays a role, in particular the political feasibility of adjustment. Indeed, theory has long emphasized that sovereign debt is different from corporate debt, precisely because politics and institutions are crucial in determining a country's capacity and willingness to repay. ${ }^{2}$ From this perspective, debt sustainability would depend, among other things, on the particular political coalition, the strength of political institutions, and even on the egos of decisionmakers and their negotiating power, both at home and abroad. Thus, debt sustainability would not only be unobservable and country-specific but also time-varying and highly volatile. Political positions can change very rapidly, as showcased by the turmoil caused by the Greek government's turnover in January 2015.

However, this is a perspective that neither the IMF nor the eurozone can adopt. As a matter of principle, they must ensure equal treatment across members and cannot constantly change the goalposts in accordance with shifting political circumstances. Thus, they need to deploy a framework to assess debt sustainability that can be applied to the entire membership. ${ }^{3}$ In addition, this framework should be designed with the goals of both protecting the debtor country from overborrowing and protecting the resources of the creditor institution. An "unsustainable" verdict should preclude the official sector from lending into cases of insolvency and should require some form of debt restructuring first (IMF 2014a, 2014c). Understanding the basis of official debt sustainability analysis is therefore crucial. The first contribution of this paper (section I) is to present the models for sustainability assessment employed by the IMF and the European Stability Mechanism (ESM), and then to review the impact of the Greek debt crisis on the overall framework for international crisis lending.

2. A large body of theoretical literature emphasizes this point, starting with Eaton and Gersovitz (1981) and summarized extensively in the surveys by Eaton and Fernandez (1995); Panizza, Sturzenegger, and Zettelmeyer (2009); and Aguiar and Amador (2014). The empirical literature has identified many political and institutional factors that have an impact on the probability of sovereign default; for example, see Van Rijckeghem and Weder (2009), Tomz and Wright (2013), and Sandleris (2015).

3. In its analytical framework, the IMF (2013b, p. 4) does make a reference to the political feasibility of primary balance adjustments, but this does not seem to depend on the country-specific political situation. 
The paper's second contribution (section II) is to evaluate present Greek debt sustainability in light of these models. We show that neither of the current frameworks sufficiently takes into account the extent of Greece's dependence on official sector funding. We analyze Greek debt using a present-value approach to account for the concessionality element. Our main finding is that the overall debt contains a grant element of 37 percent and the European loans of up to 60 percent. We also show an analysis of projected repayment flows, or gross financing needs. While the main projection shows a critical level of more than 15 percent over the long term, this result is highly sensitive to assumptions about market conditions in the coming decades.

We are not the first to argue that the face value of (gross) sovereign debt may be a misleading measure. For rich but highly indebted countries like Japan, it has long been suggested that government debt should be measured in net rather than gross terms by deducting the value of government assets from the debt stock (IMF 2013b). A more recent suggestion is that sovereign debt should be expressed according to international accounting standards, including measuring the debt stock at fair values (Serafeim 2015; Kazarian 2015). We are more in line with Daniel Dias, Christine Richmond, and Mark Wright (2014), who show that measuring debt in present value, rather than face value, enables cross-country comparisons and discourages the hiding of true indebtedness behind convenient debt profiles. But our main point applies to Greece and countries borrowing from the ESM. For them, looking at gross debt will lead to a misdiagnosis, because it does not appreciate the concessional nature of European crisis lending.

The remainder of the paper is organized as follows. In section I, we discuss the role of debt sustainability analysis within the European and IMF crisis-lending frameworks. In section II, we highlight the uncertainty of Greek debt sustainability. And in section III, we provide our policy conclusions.

\section{The Official Sector's Lending Framework and the Role of Debt Sustainability Analysis}

The lending frameworks of the IMF and the ESM set the parameters under which countries in financial distress are considered illiquid, rather than insolvent, and can therefore receive emergency financing without first restructuring existing debt. The principle of committing to not lend into unsustainable debt dynamics is justified by several reasons, most importantly by the need to protect taxpayer resources and prevent the debtor from 
accumulating excess debt, which would make future adjustment and eventual restructuring more costly. Nevertheless, this commitment is regularly tested, since the official sector will be tempted to lend even in highly doubtful cases, hoping that conditions will improve, and thus avoid the immediate costs of a restructuring, a policy known as "kicking the can down the road." The temptation to lend into insolvency is even larger if there are fears of global or regional contagion resulting from a restructuring.

Consequently, debt restructurings tend to do too little, come too late, and are too costly (Levy Yeyati and Panizza 2011; IMF 2013a). Moreover, such time-inconsistent policies of official lenders may result in overborrowing. The presence of an international lender of last resort creates incentives for private creditors to lend without regard for risk in the expectation of an official bailout. The costs of overborrowing and delayed restructuring are then mostly borne by local taxpayers, since official lenders tend to be repaid (Buchheit and others 2013). By governing the decision to provide emergency funds or insist on debt restructuring and relief first, the lending frameworks of the IMF and ESM in practice act as sovereign debt restructuring regimes. The analysis of debt sustainability is their main gatekeeper.

\section{I.A. The ESM and IMF Crisis Lending Frameworks}

The European crisis lending framework, as laid out in the 2012 treaty establishing the ESM, provides for rule-based decisionmaking for the granting of emergency loans. Article 13 requests that an application by a member state will be considered based on an assessment of three criteria through the European Commission (EC) in conjunction with the European Central Bank (ECB): (i) The risks to the financial stability of the euro area as a whole; (ii) the sustainability of public debt (if appropriate, in conjunction with the IMF); and (iii) the actual or potential financing needs of the applicant member state.

In principle, ESM loans will only be extended if the member state's public debt is sustainable. However, the treaty does not give clear guidance on how to proceed if the results of the ESM-EC-ECB debt sustainability analysis indicate an unsustainable situation. ${ }^{4}$ Specifically, there are no provisions that would require a debt restructuring to unlock ESM access in a case where the sustainability analysis suggests an unsustainable debt.

4. In the following, we refer to the debt sustainability analysis framework mentioned in the European Stability Mechanism treaty, which is conducted jointly by the European Commission and European Central Bank, as the "ESM framework." 
The IMF's lending "of last resort" to countries in financial trouble is based on multiple variables. First and foremost, a country's maximum loan volume is determined by its "quota" - a blended measure of a nation's GDP, financial openness and volatility, and official reserves (IMF 2008). In normal circumstances, countries are allowed to borrow up to 200 percent of their quota during a 12-month period, and not more than a cumulative 600 percent of their quota. The Greek quota, for instance, currently stands at SDR 1.1 billion, or about $\$ 1.5$ billion, which would have limited the maximum Greek borrowing from the IMF to about $\$ 9$ billion. ${ }^{5}$ However, in exceptional circumstances, member countries are allowed to borrow more than the normal limits under the "exceptional access" policy. ${ }^{6}$ To obtain exceptional access under the rules prevalent at the time of the first Greek program, four criteria had to be met (IMF 2004, p. 4):

i. The country is under exceptional balance-of-payments pressure exceeding the normal limits.

ii. A debt sustainability analysis indicates a high probability that the debt will remain sustainable. If the debt sustainability analysis cannot conclude this with high probability, exceptional access may be granted on grounds of systemic concerns (a "systemic exemption").

iii. The country has good chances of regaining access to private markets before the bailout ends.

iv. The country has a policy program convincingly promising success, as well as the institutional quality to implement the program.

As with the ESM framework, the IMF's framework requires an in-depth debt sustainability analysis of the country's debt stock. Before the introduction of the systemic exemption, the outcome of this analysis determined whether debt restructuring was required before a loan could be granted (IMF 2014c). Only if the debt level was deemed sustainable with high probability could exceptional access be granted without recourse to debt

5. The IMF's country quotas are expressed in terms of SDRs (Special Drawing Rights), the IMF's reserve asset based on a basket of four major currencies.

6. Access to this exceptional credit facility is determined by additional variables beyond the country quota. Providing large loans to countries in financial distress comes at greater risks, and granting exceptional access has therefore been controversial ever since Mexico received the first such loan of 688 percent of its quota in 1995 (IMF 1995). With the experience of further emerging markets crises in the 1990s in mind, the IMF formalized this instrument in the early 2000s (IMF 2002, 2004). 
restructuring. The introduction of an exemption in cases of systemic concerns was therefore a major softening of the lending framework.

\section{I.B. The Softening of the Lending Framework in Response to the Greek Crisis}

European and international institutions of crisis lending were profoundly affected by the Greek crisis. In the case of the eurozone, the crisis led to the very creation of a multilateral institution for emergency financing. The previous regime only foresaw offering financial assistance for balance-ofpayments crises in European Union (EU) members outside the eurozone. Inside the eurozone, fiscal crises were to be avoided by the threat of "no bailouts," as enshrined in Article 125 of the Treaty on the Functioning of the European Union.

The Greek crisis exposed the time inconsistency of the "no bailout" promise. Faced with the threat of an imminent Greek sovereign default and high uncertainties about the direct and indirect costs of a default to the monetary union, eurozone member states found a quick fix to circumvent the "no bailout" clause: They granted a credit line of up to $€ 80$ billion in bilateral loans through a special vehicle, the Greek Loan Facility (GLF). ${ }^{7}$ This exceptional vehicle was replaced first with the creation of a multilateral structure (the European Financial Stability Facility, EFSF) and then through a treaty establishing the permanent ESM.

Introducing a permanent facility for emergency financing amounted to a significant reform of the eurozone architecture. It added a supranational fiscal buffer for large crises and established a new regime of conditional bailouts. As noted above, three criteria for access to ESM funding are the main governors of this new regime, and should ensure that loans are extended only in cases of sustainable debt dynamics. However, the first and the third criteria are bound to be fulfilled in any crisis. If any default or restructuring is considered to raise doubt about the "integrity of the euro area as a whole," this test becomes meaningless as a commitment device. ${ }^{8}$ Thus, the only real test is the analysis of debt sustainability.

The Greek debt crisis further affected the European financial architecture as loans from European partner countries were being restructured.

7. The volume eventually borrowed was $€ 52.9$ billion.

8. This interpretation was confirmed by the assessment of the Greek loan application of July 2015. The EU concluded that although direct financial risks of a Greek default were small, they would create "significant doubts on the integrity of the euro area as a whole, currently and in the future" (European Commission 2015, p. 5). 
As presented in detail below, Europeans made a series of concessions and restructured their original loans multiple times. This official restructuring was silent but had a permanent impact on the Greek debt profile and on the institutions for crisis lending in Europe. The conditions of Greek loans were passed on to other crisis countries and became a de facto new ESM lending policy. As a consequence, European crisis lending conditions are now highly concessionary, with average maturities of up to 32.5 years, decade-long grace periods, and a pass-through of ESM funding costs to program countries. These lending terms are closer to those of the World Bank for long-term lending to low-income countries than to IMF-type, short-term balance-of-payments assistance. ${ }^{9}$

For the IMF, the first Greek program also brought about an important change in lending policies. The May 2010 stand-by program granted Greece exceptional access to draw $€ 30$ billion, more than 3,000 percent of its quota. The yardstick for granting such a high level of access was the debt sustainability criterion. Under the baseline scenario, the IMF projected Greece's public debt as a share of GDP to peak in 2013 at 149 percent and to gradually decline by 2020 to 120 percent, although it flagged many risks to this baseline scenario (IMF 2010a). On balance, the IMF considered debt to be sustainable over the medium term; however, it noted that the significant uncertainties "make it difficult to state categorically that this is the case with a high probability" (IMF 2010a, p. 20). Under the then-existing "exceptional access" policy, this statement would have precluded the IMF from approving the program without first requiring debt restructuring. The quick-fix solution was to introduce a "systemic exemption" from the rule due to the high risk of international spillovers.

This solution implies that the IMF could lend to insolvent countries, provided that spillovers are seen to be large..$^{10}$ The systemic exemption eventually became a permanent feature of IMF exceptional access policies

9. The maximum term on World Bank loans, under the International Bank for Reconstruction and Development, is 35 years, with an average weighted maturity of 20 years (World Bank 2014). Nonconcessional IMF loans are due much earlier, with final maturities from 3.25 to 5 years for Stand-By Arrangements and 4.5 to 10 years for the Extended Fund Facility; even for concessional loans, the IMF expects repayment within 8 to 10 years (IMF 2015c).

10. The fact that this constituted a change in policies was not obvious to the board and led to a heated discussion once one director pointed it out. The directors first thought that this exception would only be applied to Greece, but the Legal Department of the IMF explained that it would carry over to all member countries due to equal treatment requirements (IMF 2010b). 
(IMF 2014c). ${ }^{11}$ A former director of the IMF, Susan Schadler, put it like this: "The framework constraining the discretion of the IMF in severe debt crises broke down in its first serious test" (Schadler 2013, p. 14). ${ }^{12}$ IMF staff members have proposed eliminating the systemic exemption on the grounds that it is inequitable and excessively open ended. ${ }^{13}$ Instead of keeping the vague option of extending loans on grounds of systemic risk concerns, a recent staff proposal suggested that a one-time debt reprofiling (prolongation of maturities without reduction in principal or interest) should always be required in cases of doubtful debt dynamics (IMF 2014a). ${ }^{14}$ By January 2016, the main shareholders of the IMF had accepted this argument, and the IMF announced a new lending policy abolishing the systemic exemption (IMF 2016).

However, the verdict on debt sustainability still constitutes an important condition for access to IMF and ESM lending. We next turn to the mechanics of these analyses.

\section{I.C. The Mechanics of IMF and ESM Debt Sustainability Analysis}

Both the IMF's and ESM's methodologies for analyzing debt sustainability require an analysis of the debt stock in a static framework using observed data about the current situation and in a dynamic framework using forecast data (IMF 2013b, 2013d; European Commission 2014). Forecasting requires a comprehensive macroeconomic model that at a minimum includes growth, inflation, interest, and exchange rates, as well as fiscal policies, and is therefore subject to uncertainty. Besides the benchmark assumptions, the data are also exposed to a series of robustness checks and stochastic analyses in which alternative data trajectories are considered..$^{15}$

The results of these exercises, along with the static indicators, are then compared with a set of thresholds that designate an increased risk of debt

11. The systemic exemption has already been invoked 34 times for eurozone programs and reviews.

12. Schadler (2013) also discusses whether Greece really presented circumstances that warranted changing the lending criteria. She distinguishes between the immediate momentwhen the counterfactual to the IMF's involvement would have entailed large systemic costand the continuing involvement of the IMF over the following years.

13. Moreover, it may increase the risk to the IMF's own resources and its seniority status, as evidenced by the default of Greece on payments to the IMF in the summer of 2015.

14. During the board discussion of this proposal, some directors preferred to keep the systemic exemption as a "pragmatic way to safeguard financial stability in an increasingly integrated world and avoid the perception of lack of evenhandedness" (IMF 2014b).

15. In particular, this includes negative shocks to the primary balance, real GDP growth, nominal interest rates, the exchange rate, and contingent liabilities. 
distress. These thresholds are derived by running early warning systems, in the spirit of the "signaling approach" suggested by Graciela Kaminsky, Saul Lizondo, and Carmen Reinhart (1998); Kaminsky and Reinhart (1999); and Emanuele Baldacci and others (2011). A related alternative is the regression-based approach suggested by Aart Kraay and Vikram Nehru (2004). In the signaling approach, a signal of an impending crisis is triggered if the realized value of a set of macroeconomic and financial variables exceeds a critical value of the variable's distribution. If a signal is triggered and a crisis erupts in the following predefined projection period (such as the 24-month period in Kaminsky and Reinhart [1999]), the signal is recorded as a "good" positive; if no crisis occurs, it is counted as a "false" positive. Likewise, if there is a crisis but no signal has been recorded in the preceding projection period, every observation without a signal is recorded as a "false" negative. If no crisis erupts, and no signal was triggered, the observation counts as a "good" negative signal. The critical value of the distribution is chosen so as to minimize the equally weighted sum of false positive and false negative signals.

For instance, in the analysis by Kaminsky and Reinhart (1999), the threshold of the deficit-to-GDP ratio that minimizes the sum of false positives and false negatives is the 86th percentile of the historical deficit distribution. If a country's realized deficit in any given year exceeds the 86th percentile of that country's distribution of deficits, a crisis signal is triggered. While the original contributions by Kaminsky, Lizondo, and Reinhart (1998) and Kaminsky and Reinhart (1999) suggest countryspecific distributions, the approach used today by the IMF (Baldacci and others 2011; IMF 2013b) and the ESM (Berti, Salto, and Lequien 2012; European Commission 2014) chooses thresholds based on the pooled distributions of all countries in the sample.

Similarly, the IMF thresholds for low-income countries are derived from a regression model in which a crisis indicator is regressed on the threshold variables; the maximum thresholds are then set so that the predicted crisis probability remains below predefined values (Kraay and Nehru 2004).

Table 1 shows the thresholds for the various frameworks. While the ESM does not distinguish between different countries, the IMF framework has different variables for market-access and low-income countries. In addition, the values for advanced economies and emerging markets are different, and within low-income countries values are further differentiated according to the institutional quality.

A country is only considered at low risk of debt distress if its debt stock and predicted future development do not exceed these thresholds, 


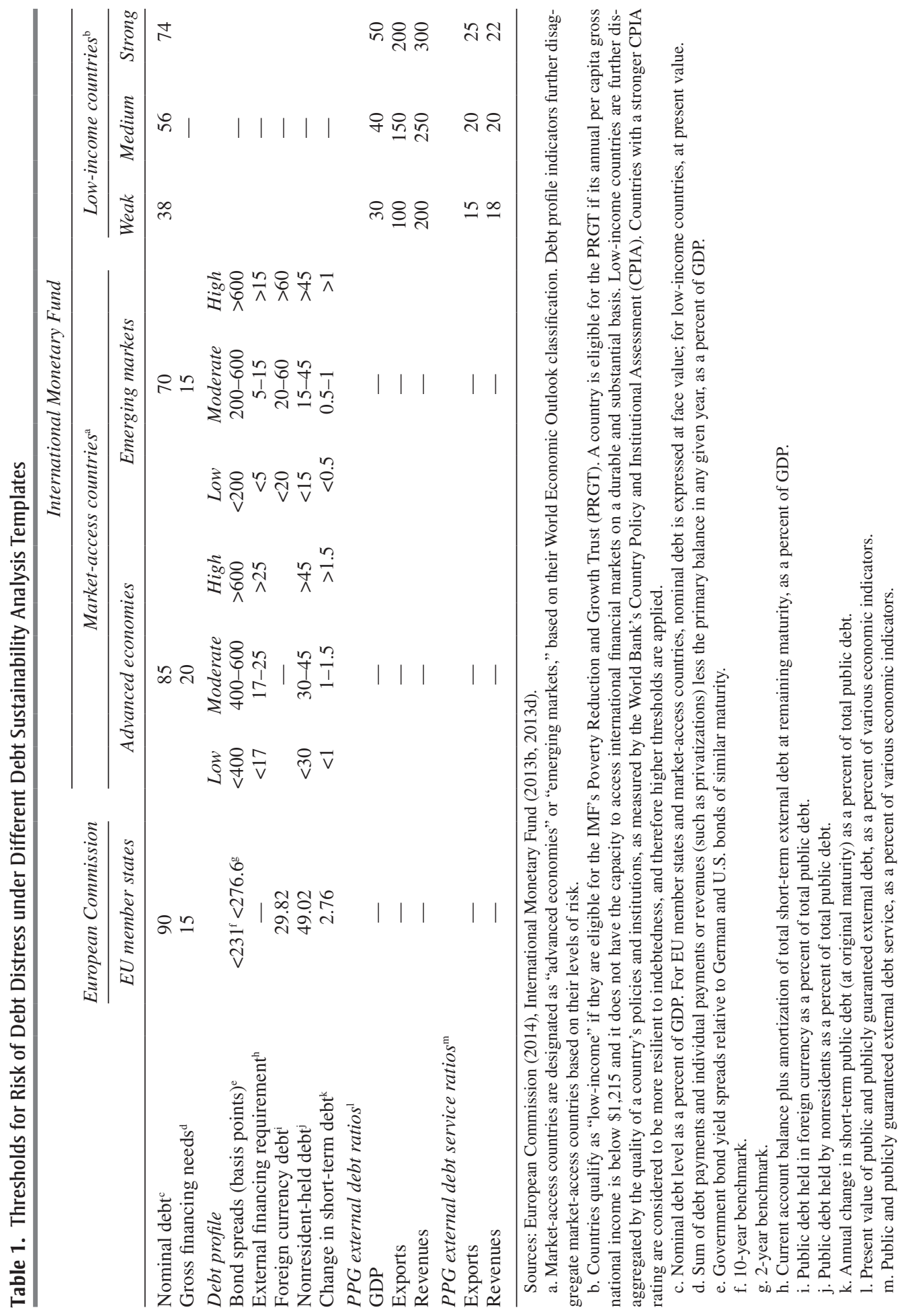


both under the benchmark scenario and under the robustness scenario with more negative assumptions. If the indicators exceed the thresholds in the baseline scenarios, the probability of debt distress is considered high. The middle ground is more ambiguous; a moderate risk rating is assigned if the thresholds are breached in the robustness scenarios but remain below the critical values under the baseline assumptions.

The general framework is therefore similar for all countries, in both the IMF framework and the ESM framework. However, the IMF analysis significantly differentiates between low-income countries and market-access countries along at least two dimensions that are not contained in the ESM analysis, as follows.

First, as the name suggests, market-access countries are assumed to borrow predominantly at market terms from market sources. This requires specific assumptions about the type and cost of market financing, including modeling the coupon, maturity, and currency structure of the debt. For low-income countries, borrowing from capital markets is considered an option, but many low-income countries rely mostly on official financing.

Second, for market-access countries, the stock of debt is considered at nominal values. The liabilities therefore only consist of the principal repayments, without taking into account coupon payments or the life of a debt instrument. The face-value measure of the debt stock, $F V$, is thus given by

$$
F V=\sum_{t=0}^{T} A_{t},
$$

where $A_{t}$ represents principal repayments in year $t$.

This is different for low-income countries, which receive most of their financing from official sources and whose debts are computed and analyzed in discounted present values. The present value, $P V$, is computed to include all discounted cash flows of the principal, $A_{t}$, and coupons, $C_{t}$ :

$$
P V=\sum_{t=0}^{T} \frac{C_{t}}{(1+d)^{t}}+\frac{A_{t}}{(1+d)^{t}} .
$$

When computing meaningful present values, the key decision is choosing an appropriate discount rate, $d$. In the current IMF framework, $d$ is set to a constant rate of 5 percent (IMF 2013c). This choice is justified by the fact that a more elaborate discounting model would increase the degrees of freedom in the analysis, thereby making cross-country comparisons more difficult. Conceivable alternatives that have been discussed in the 
literature range from the London Interbank Offered Rate (commonly known as LIBOR) (Easterly 2001), to higher (constant) rates of between 7 and 10 percent (Chauvin and Kraay 2005; Andritzky 2006; Dikhanov 2006), to discounting based on the country's (or a reference country's) sovereign yield curve (Cruces and Trebesch 2013). In this paper, we do not take a stance on which of these approaches should be preferred; instead, to maximize comparability, we apply the IMF's discount rate of 5 percent. ${ }^{16}$

Both $F V$ and $P V$ only measure debt stocks, without taking into account funding pressures in any given year. To complement the analysis for this dimension, the gross financing needs, $G F N$, measure the difference between the debt service obligations and the government's available income for debt payments, the primary balance, $P B$ :

$$
G F N_{t}=A_{t}^{*}+C_{t}^{*}+A_{t}^{N}+I_{t}^{N} F V_{t-1}^{N}-P B_{t},
$$

and

$$
F V_{t}^{N}=F V_{t-1}^{N}+G F N_{t}-A_{t}^{N}=\sum_{i=0}^{t} G F N_{i}-A_{i}^{N}
$$

where $A_{t}^{*}$ and $C_{t}^{*}$ denote the debt repayments and interest that are already scheduled as of the date of the analysis, $A_{t}^{N}$ denotes the repayment of newly issued debt to cover previous periods' $G F N, I_{t}^{N}$ represents the interest burden on newly issued debt, and $F V_{t}^{N}$ is the stock of newly issued debt. The future refinancing terms of the projected funding shortfalls- that is, the interest rate and maturity of newly issued debt—must be assumed. For instance, under an assumed maturity of 5 years, $A_{t}^{N}$ will be equal to $G F N_{t-5}$.

\section{Debt Sustainability Analysis in Greece: Past and Present Shortfalls}

Ideally, the mechanical application of these tools should provide a clear result if a government's public finances are sustainable or not-independently of whether such a result is taken seriously in official lending frameworks. Yet in practice, significant uncertainties open a wide range of possible outcomes of the analysis, not least because it requires assumptions about the feasibility of future budgetary assumptions (House and Tesar 2015).

16. In the online appendix, we report alternative results based on Greek and German market-discount rates. Online appendixes to all papers in this volume may be found on the Brookings Papers webpage, www.brookings.edu/bpea, under "Past Editions." 
Figure 1. Four Stages of (Mis-)Diagnosed Greek Debt Sustainability

Debt projection, percent of GDP

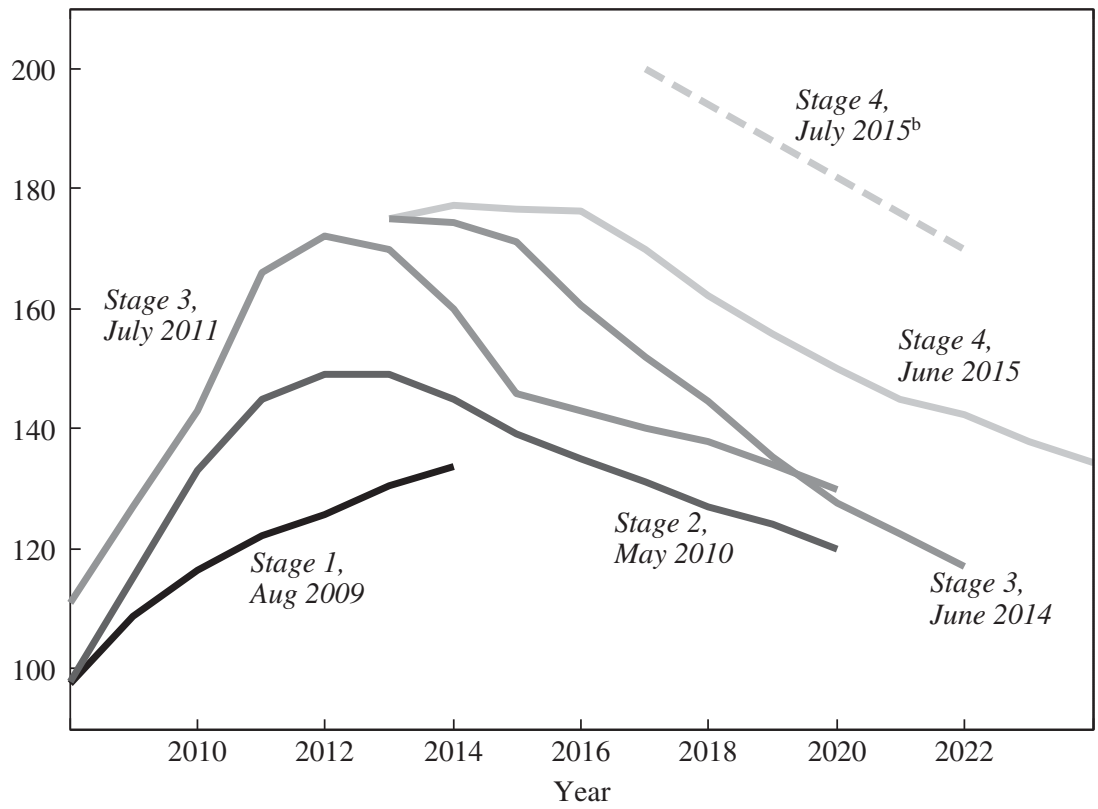

Source: International Monetary Fund (2009, 2010a, 2011, 2015a, 2015b).

a. Shows the debt projections as a percent of GDP from the IMF's debt sustainability analyses at the four stages described in the text.

b. The latest publication from July 2015 did not contain a full analysis, but only two data points: a peak at close to 200 percent within the next two years, and a reduction to 170 percent in 2022 . The dashed line represents the lack of full data.

\section{II.A. Serial Misdiagnoses and Restructuring}

Indeed, over the course of the Greek crisis, debt dynamics have been repeatedly underestimated. We divide the recent history into four stages, with the first stage starting in the fall of 2009 (figure 1). At that time, Greece was already in an "Excess Deficit Procedure" for breaching the limits of the Maastricht Treaty, and it had committed to bringing its deficit back to 3 percent of GDP during the coming year. In the summer of 2009, the IMF estimated the current deficit at 6.2 percent and warned that debt dynamics would become unsustainable unless policies were radically changed (IMF 2009). The debt-to-GDP ratio was expected to rise above 100 percent in 2009 and to increase further, to more than 120 percent, within 2 years. The IMF analysis concluded that fiscal consolidation was immediately required to achieve sustainability but that fairly modest adjustments of 1.5 percent 
of GDP would be sufficient. In October 2009, Greece revealed new deficit estimates of up to 12.5 percent, at the same time acknowledging that it had misreported previous numbers, which also turned out to be substantially higher. ${ }^{17}$ Concerns about fiscal sustainability deepened and triggered a confidence crisis.

The second stage began in May 2010 with the first joint bailout by eurozone governments and the IMF. While the dynamic was seen as considerably more negative than before and the debt stock was seen to peak at close to 150 percent of GDP, the verdict was still that the debt was sustainable, if not with high probability. The official loans were justified by invoking the systemic exemption for the first time and trusting that debt restructuring would not be necessary.

The third stage was the time of reckoning, reached in mid-2011, when official sector creditors acknowledged that debt restructuring was unavoidable (IMF 2011). The well-publicized and well-documented part of this stage was the restructuring of private debt, which took place in March 2012. The process involved retroactively changing bond contracts by legislative action and a good measure of coercion by governments on financial institutions; but the result was a high participation rate and a severe haircut, with present value reduction of over 60 percent (Zettelmeyer, Trebesch, and Gulati 2013).

The official sector restructuring was more silent. Over time, European public sector loans were restructured, deeply and repeatedly. Table 2 shows the timeline for Greek debt restructurings through the two main public loan vehicles for Greece, the GLF and the EFSF. Interest rates on bilateral loans in the GLF were lowered in three steps between 2010 and 2013, reducing the interest margin over the floating 3-month Euro Interbank Offered Rate (commonly known as EURIBOR) from 300-400 basis points to 50 basis points. Even more pronounced were the extensions of the grace period, from 3 to 10 years, and of the maturity, from 5 to 30 years. EFSF loan conditions were restructured in a similar way, most importantly by almost

17. Moreover, Eurostat noted that it could not verify the new figures and flagged the risk of further upward revisions. The ministers of the Economic and Financial Affairs Council immediately mandated the European Commission to investigate. The resulting report concludes that the quality and the governance of Greek fiscal statistics are seen as insufficient, noting that "revisions of this magnitude ... have been extremely rare in other EU Member States, but have taken place for Greece on several occasions" (European Commission 2010, p. 3).

18. The conditions of EFSF lending were amended accordingly, and the other EFSF program countries-Ireland and Portugal—similarly benefited from debt relief in the form of significantly increased maturities. The maturity on Ireland's loan was increased from 2016-29 to 2029-42, and on Portugal's loan from 2015-38 to 2025-40, increasing the average weighted maturity to more than 20 years (EFSF 2013a, 2013b). 


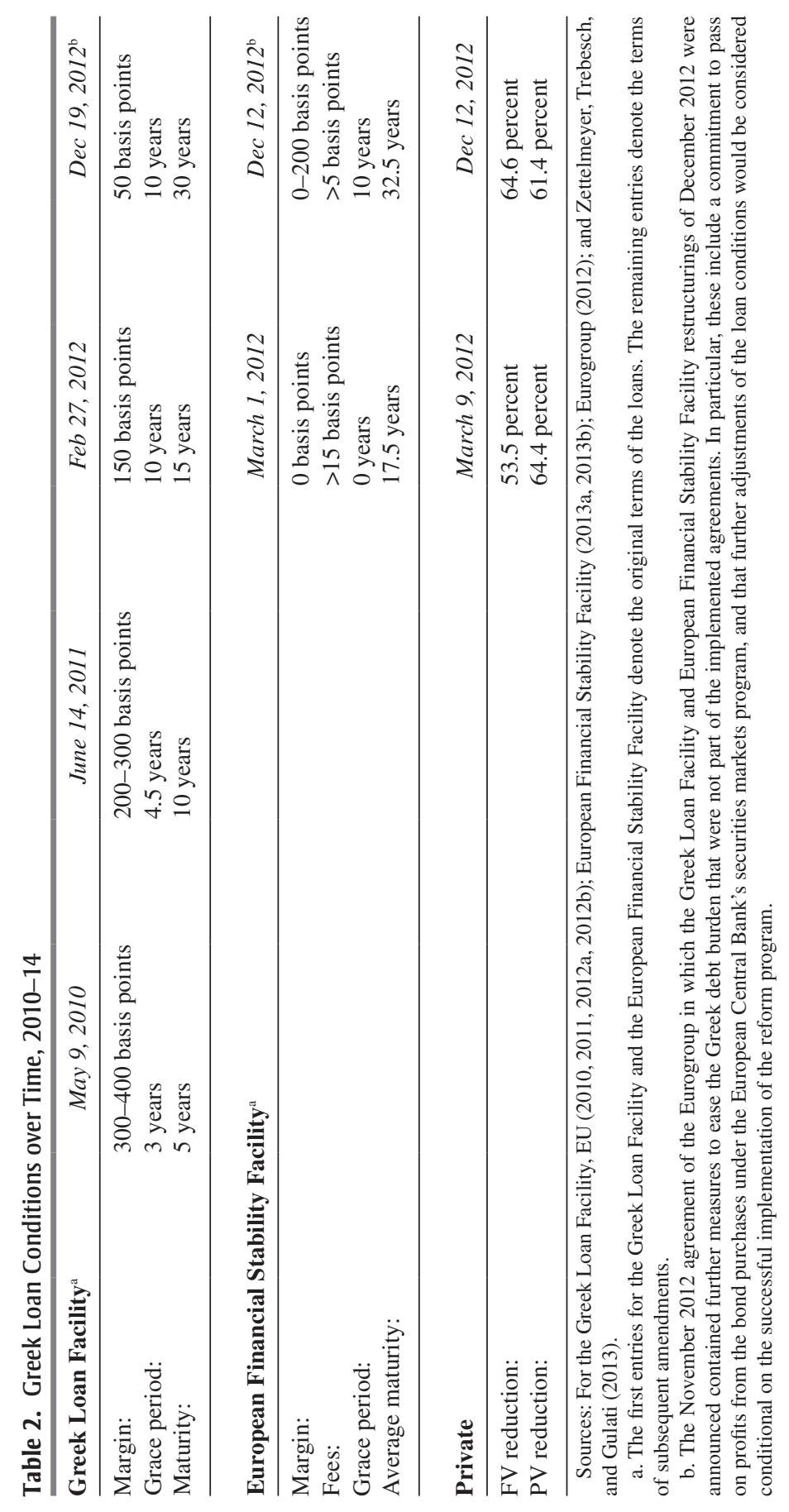


doubling the average maturity of the loans to more than 30 years. ${ }^{18} \mathrm{ESM}$ lending policies were later aligned.

After the combined private and official debt relief, the troika concluded that Greek debt was finally sustainable. Moreover, the assessment became gradually more optimistic, and the IMF released a new debt projection in June 2014. For the first time, no further increase in the debt stock was projected-it seemed that the peak had been left behind. By the beginning of 2015, the troika viewed Greece as being on a good path. In its request to the German parliament for an extension of the Greek program, the German Ministry of Finance justified the extension with a "confirmation of debt sustainability" by the European Commission, and explained that the "debt sustainability has improved since the last program review of April 2014" (German Ministry of Finance 2014, p. 4).

The fourth and ongoing stage is characterized by conflict between official creditors about debt sustainability, which at the time of this writing remains unresolved. The IMF has made debt relief a condition for participation in a third Greek program. In July 2015, it published two new debt projections within a short time. It then argued that the systemic exemption can no longer be invoked for Greece and that it will not participate in funding a new program unless there is further debt restructuring on the European side. The Europeans have decided to go ahead with financing without restructuring the existing loans again, leaving burden sharing within the official sector an unresolved conflict.

\section{II.B. Uncertainties in the Analysis of Greece's Debt Stock}

While Greece had been exclusively relying on private financing between the introduction of the euro and the start of the European sovereign debt crisis in 2009, Greek debt today is dominated by official loans. As of the end of July 2015, before the third program had been negotiated, more than 80 percent of its current outstanding debt was owed to official creditors. The average maturity was 15.7 years, with an average interest rate of 2.7 percent. ${ }^{19}$

Figure 2 shows the debt repayment profile of Greece by creditor. ${ }^{20}$ Only the relatively large amount of short-term debt (Treasury bills) and the remaining holdout bonds that were not restructured in 2012 require repayments to private investors within the next 8 years. Afterward, the remaining

19. See Public Debt Management Agency (2015). To put this in perspective, the average maturity terms of Italian and French sovereign debt are 6.5 and 6.9 years, respectively (Italy, Department of the Treasury 2015; France, Treasury Agency 2015).

20. Not including the new ESM program. 
Figure 2. Greek Debt Repayment Profile (Face Value) by Creditor, 2015-54

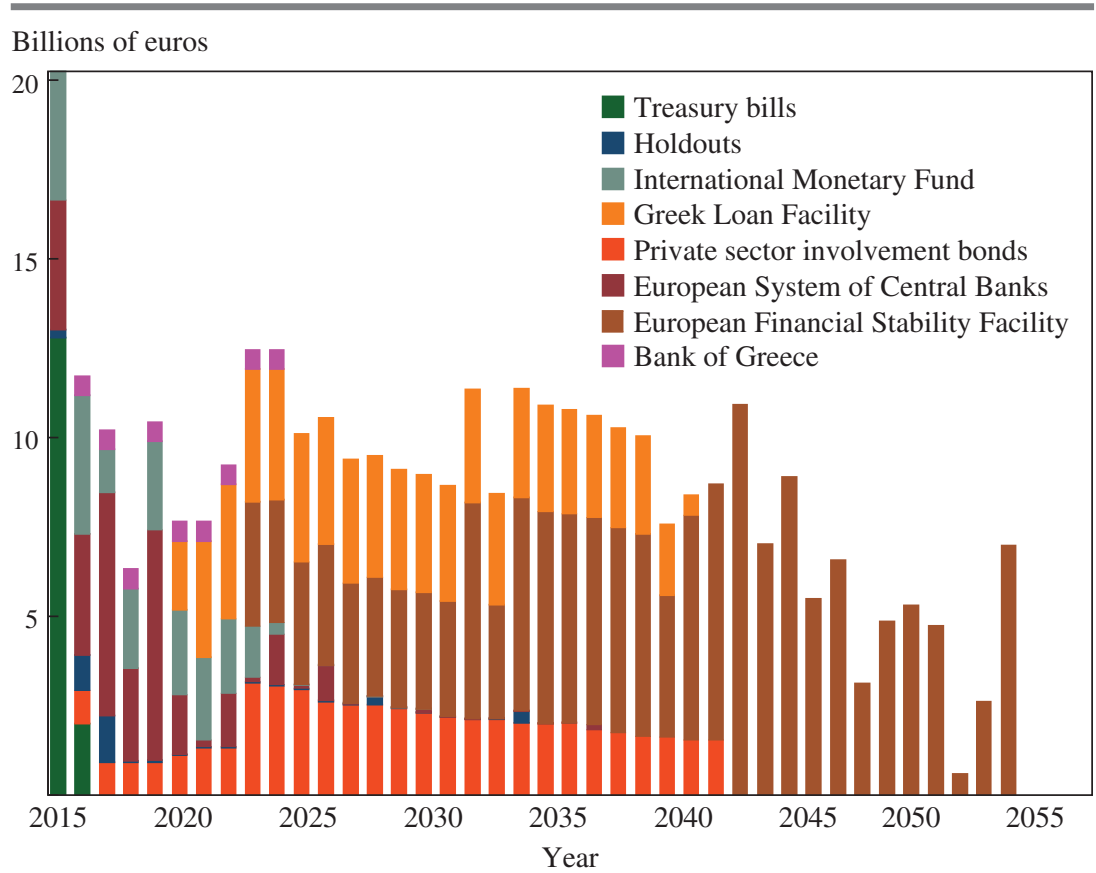

private sector involvement (PSI) bonds amortize over a period of 20 years, stretched out through the maturity extensions of the 2012 debt restructuring. The bulk of the debt is owed to the EFSF; to other eurozone governments through the GLF; to the IMF; to the ECB; and to other members of the European System of Central Banks. Notably, the official European loans through the GLF and the EFSF only start becoming due in 2020 and 2023, respectively, and repayments are stretched out until 2054.

As explained above, the official loans are extended at highly favorable terms (table 3 ). This generates a significant element of concessionality. Using the discount rate of 5 percent to compare the face value of the EFSF and GLF loans to their present value reveals considerable "grant elements" of up to 61 percent. On average, the Greek debt stock contains a grant element of 37 percent. $^{21}$

The recently negotiated third program over $€ 86$ billion is likely to increase this concessionality. The new ESM program will have the same 32.5 year

21. A previous version of these and the following computations can be found in Schumacher and Weder di Mauro (2015). 
Table 3. Greek Debt Composition

\begin{tabular}{|c|c|c|c|c|}
\hline Debt & $\begin{array}{c}\text { Face } \\
\text { value }^{\mathrm{a}} \\
\text { (billions of }^{\text {euros) }}\end{array}$ & $\begin{array}{l}\text { Interest }^{\mathrm{b}} \\
\text { (billions of } \\
\text { euros) }\end{array}$ & $\begin{array}{l}\text { Present } \\
\text { value }^{\mathrm{c}} \\
\text { (billions } \\
\text { of euros) }\end{array}$ & $\begin{array}{c}\text { Grant } \\
\text { element } \\
\text { (percent) }\end{array}$ \\
\hline Treasury bills & 14.8 & - & 14.6 & $\mathrm{n} / \mathrm{a}$ \\
\hline Private sector involvement bonds & 30.5 & 20.7 & 26.8 & 12 \\
\hline Holdout bonds & 2.8 & 0.7 & 2.9 & -2 \\
\hline Bonds held by the Eurosystem ${ }^{\mathrm{e}}$ & 23.6 & 4.9 & 24.2 & -2 \\
\hline International Monetary Fund & 19.5 & 2.5 & 18.6 & 5 \\
\hline European Financial Stability Facility & 131.0 & 27.8 & 51.4 & 61 \\
\hline Greek Loan Facility & 52.9 & 13.5 & 33.2 & 37 \\
\hline Bank of Greece ${ }^{f}$ & 4.8 & - & 3.8 & $\mathrm{n} / \mathrm{a}$ \\
\hline Total (without new program) & 280.1 & 70.0 & 175.6 & 37 \\
\hline Percent of GDP & 156 & & 98 & \\
\hline \multicolumn{5}{|l|}{ New program $^{\mathrm{g}}$} \\
\hline European Stability Mechanism & 77.8 & 31.7 & 31.9 & 59 \\
\hline International Monetary Fund & 8 & 1 & 8 & 8 \\
\hline Total new program & 86.0 & 32.7 & 39.5 & 54.1 \\
\hline Total & 366.1 & 102.6 & 215.1 & 41.2 \\
\hline Percent of GDP & 204 & & 120 & \\
\hline
\end{tabular}

Sources: IMF (2013d), for the definition of the grant element; for the data, the various data sources cited in the paper (IMF, GLF, EFSF).

a. Sum of principal payments, as in equation 1 .

b. Undiscounted sum of interest payments due to each creditor.

c. Discounted sum of principal and interest payments, as in equation 2.

d. Defined as (face value - present value) / face value.

e. Includes bonds held by the European Central Bank, the European Investment Bank, and various national central banks.

f. Assuming constant amortization.

g. Assuming the new program is identical to the previous programs with respect to the share of IMF and European lending.

average maturity as the EFSF loans, with amortizations beginning in 2034, and similarly favorable interest rates. Assuming that the IMF will contribute circa 10 percent of the total volume, in line with the currently outstanding share of IMF and European commitments, and request a maturity of 5 years, the average grant element will rise to more than 40 percent.

\section{II.C. Uncertainties in the Analysis of Flows}

In its most recent debt sustainability analysis, the IMF has expressed a similar judgment. Furthermore, the IMF has acknowledged that the nominal gross debt-to-GDP ratio is no longer a meaningful metric to evaluate 
Figure 3. Gross Financing Needs over the Long Term, 2015-70

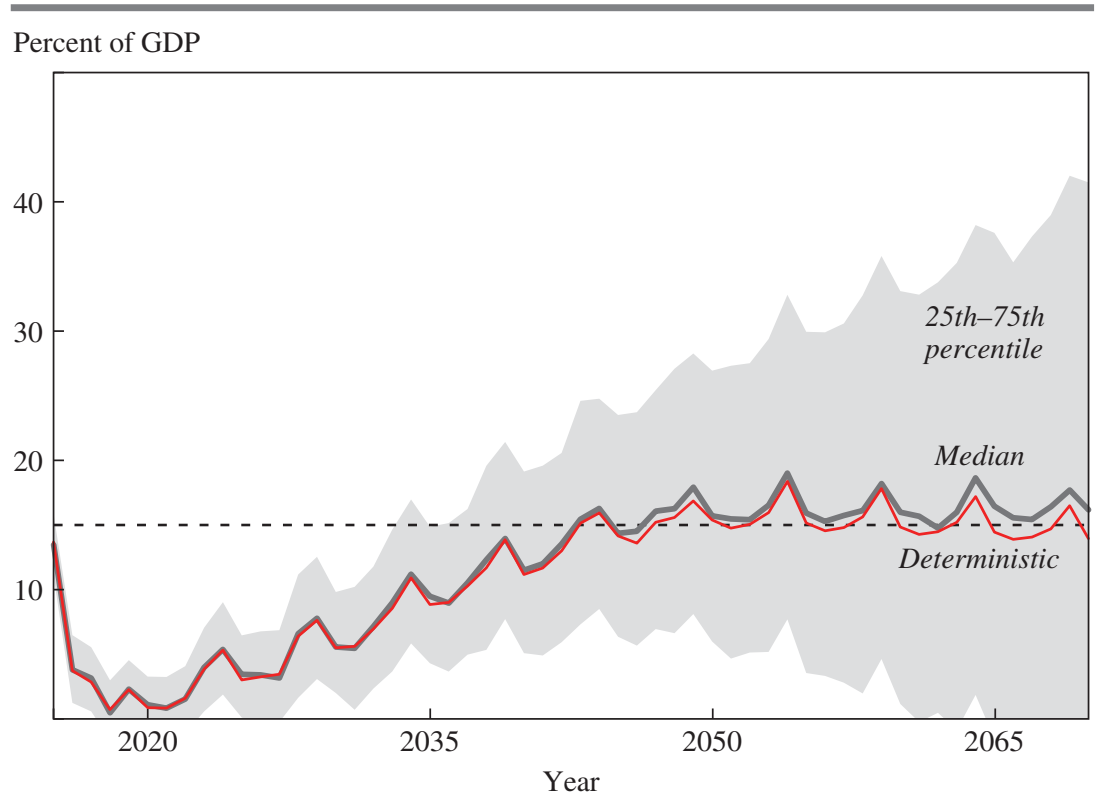

sustainability (IMF 2015a, p. 11). The recent analysis suggests that gross financing need (GFN) should be looked at instead, as these needs capture the funding pressure in any given year. Using values similar to those indicated in the recent IMF debt sustainability analysis (annual real GDP growth of 1.75 percent, average interest rate of 6 percent, average maturity of 5 years, and primary balance of 3.5 percent), the GFN is projected to increase relative to GDP above critical thresholds of 15 to 20 percent from the mid-2030s onward (figure 3). In the short to medium terms, however, the GFN remains below this critical value.

Two factors explain the increase in GFN from the 2030s onward. First, the European loan repayment schedules fall together with redemptions of private sector bonds after the grace periods on the official loans have ended in the mid-2020s. However, even under modest growth assumptions, the annual obligations do not exceed $€ 15$ billion, so in isolation they remain well below 15 percent of GDP. The second, more crucial factor in this analysis is therefore the refinanced debt from the relatively low GFN in the coming 10 to 15 years. Every annual funding gap is refinanced at the assumed market interest rate of 6 percent with a maturity of 5 years. Over the very-long-term horizon considered in this analysis, the compounding 
of these relatively expensive terms (as compared with today's low-interest environment) leads to the very high GFN displayed in figure 3.

For instance, the total projected debt payments in 2050 amount to $€ 62.1$ billion under the chosen parameters. Of these, $€ 42.6$ billion consists of the repayments of debt projected to be issued in 2045 to cover the financing gap in that year. Another $€ 14.1$ billion consists of the projected interest due on the outstanding debt stock, and only $€ 5.3$ billion are the interest and principal payments scheduled to the EFSF as of 2015. Together with a projected primary surplus of $€ 11.5$ billion, the 2050 GFN comes down to $€ 50.6$ billion. In other words, only about 10 percent of the GFN for that year is based on terms known today, and the remainder rests on the accuracy of the assumptions about market conditions over the coming 35 years.

This long projection horizon implies considerable uncertainty. The gray area in figure 3 displays the results of a simple Monte Carlo simulation of the projected GFN, showing the 25th and 75th percentile of realizations. ${ }^{22}$ For 2050, the interquartile range reaches from 6 to 27 percent. The policy implications of these two outcomes for the requirement of debt restructuring today would of course be fundamentally different. While a low GFN would imply healthy expected finances, a value of 27 percent would even breach the higher bound of the GFN range mentioned in table 1 by a wide margin.

The IMF has made debt operation a precondition for continued involvement in Greece and has proposed that restructuring could take the form of doubling the maturities on the European loans. However, due to the significant grant element of the EFSF and GLF loans, a pure reprofiling of this part of Greek debt will achieve a relatively smaller reduction in the present-value debt stock than an extension of maturities of earlier liabilities. Average maturities on the GLF and EFSF loans are already more than 30 years. For every $€ 1$ due in 30 years, a doubling of maturities reduces the present value of this liability by only 19 cents. Conversely, extending the term of $€ 1$ coming due next year by only 10 years reduces the present value of that obligation by 38 cents.

22. The analysis rests on 1,000 draws of independent and identically distributed shocks to the growth rate $(g)$, the interest rate $(r)$, and the primary balance $(p b)$, each drawn from a normal distribution with standard deviations matched to the historical data between 2001 (entry into the eurozone) and 2009 (last precrisis year). Specifically, for a normal distribution $N\left(\mu, \sigma^{2}\right)$, the shock distributions are $g \sim N(2.7,3.5), r \sim N(4.6,0.6)$, and $p b \sim N(-2.3,3.6)$, where $\mu$ and $\sigma^{2}$ are measured in percent. 
A debt operation that only extended the European loans would therefore be relatively less efficient in achieving present-value debt stock reductions than would a restructuring that included shorter-term liabilities. Furthermore, it would not ease financing needs until the mid-2020s, when those loans start coming due.

An extension of GLF or EFSF maturities would indeed bring down the projected GFN by reducing the amount that has to be refinanced at the assumed unfavorable market terms. But the effectiveness of such an operation rests strongly on the accuracy of the macroeconomic, financial, and fiscal projections. If market interest rates remain elevated for Greece, GDP growth remains sluggish, or a primary balance of 3.5 percent proves elusive over the next four decades, any return to private sector funding will be difficult. Conversely, a more positive outcome would make a maturity extension of the official loans obsolete.

\section{Policy Implications}

The analysis of this paper has policy implications on three levels. First, there are implications for the ongoing debate about a restructuring of Greek debt. We show that the nominal debt stock projections paint far too bleak a picture of the actual burden. Evaluated in present-value terms, Greek debt stands at about 100 percent and will rise to about 120 percent under the new program, which is not exceptionally high for advanced countries. Nevertheless, even in present-value terms, Greece still breaches the thresholds of the standard debt sustainability analysis for both market-access countries and lower-income countries. The projection of GFN over the short to medium runs, however, does not provide significant reasons for debt relief. The long-term projections, while sending signals of critically high funding pressure, are marked by very large uncertainties and thus are not a reliable basis for deciding the restructuring need.

Consequently, the debt stock and projected payment flows show that, despite the extraordinary amount of private and public debt relief Greece has already received, further debt restructuring may be advisable, although that conclusion is far less certain than commonly argued. ${ }^{23}$ If required, a debt operation should focus on the horizon over which the payment flow projections are relatively reliable and a restructuring would be relatively

23. See House and Tesar (2015) for an analysis of the required budgetary adjustments if no debt reduction is implemented. 
more efficient in reducing the debt stock. But in the short to medium runs, the repayments are mostly owed to the IMF and the ECB, and only a further extension of grace periods by the European partners would reduce the risk of default on their loans. Thus, an efficient debt restructuring will have to answer the question of burden sharing and seniority within the official sector first.

Furthermore, a mere extension of maturities without a reduction in the nominal value of long-run obligations will only extend the interdependencies of Greece and its European creditors. In their paper in this volume, Reinhart and Trebesch (2015) show that such long-term financial dependencies create significant political tensions. Political decisionmakers in the current debate should be well aware of such frictions when engaging in debt operations, which can prolong such potentially bruising negotiations for decades to come. This political economy argument speaks for outright debt relief rather than further prolongations. But a second historical lesson from Reinhart and Christoph Trebesch (2015) is that Greece has been prone to quickly overborrow again as soon as the previous debt crisis has been overcome. This suggests that debt relief should only be granted after Greece has demonstrated that it is able and willing to break away from the historical pattern, and lends support for a process like that for the Highly Indebted Poor Countries, whereby multilateral debt forgiveness is granted after an extended track record of good policy has been established.

The second set of implications concerns the mechanics of assessing debt sustainability in the official sector. Both the ESM and the IMF still apply the market-access framework to Greece, not taking into account the effective present-value debt relief that has already been granted. This is especially paradoxical in the case of the ESM, since the grant element of up to 60 percent is only contained in European loans. Nevertheless, the headline number of roughly 200 percent of nominal debt-to-GDP stock is still used in public and in negotiations. While the low-income country framework of the IMF and World Bank does account for grant elements in official lending, it does not seem appropriate for a case like Greece. In particular, the low-income country framework sets different levels for debt sustainability depending on the quality of institutions and policies. This may be sound in principle, but not feasible in practice inside the eurozone.

Finally, there are broader implications for the European monetary union as well as the international monetary system. The Greek debt crisis has profoundly changed the architecture of the eurozone. In addition to spurring reforms in EU fiscal governance, it has led to the creation of the ESM as a permanent crisis-lending mechanism. Moreover, Greece contributed to 
softening the ESM's lending framework and to transforming it from an institution like the IMF to one like the World Bank. The importance of this last step has not been sufficiently recognized. On one hand, it has implications for the ongoing debate on fiscal union, since the large grant element in European crisis lending has added a fiscal buffer. On the other hand, the repeated softening of lending conditions signals that the ESM has commitment problems and strengthens the case for establishing an effective regime for sovereign debt restructuring in the eurozone.

In contrast, the IMF's recent reforms seek to reverse the softening of its crisis lending framework. By abandoning the systemic exemption introduced in 2010, future lending decisions by the IMF should take the results of debt sustainability analyses more seriously again. Linking emergency loans to an obligatory maturity extension of existing debt if it cannot be assessed to be sustainable with high probability may help to overcome commitment problems. However, negative externalities can always be expected in cases serious enough to require exceptional access to the IMF. The framework will therefore have to stand the test of future crises to reveal the true robustness of its rules.

ACKNOWLEDGM ENTS We thank the editors, the seminar participants at the 2015 Brookings Papers Fall Meeting, and also Reza Baqir, Antonio Fatas, Nicolas Sauter, Susan Schadler, Christoph Trebesch, and Jeromin Zettelmeyer for very helpful comments. 


\section{References}

Aguiar, Mark, and Manuel Amador. 2014. "Sovereign Debt." In Handbook of International Economics 4, edited by Gita Gopinath, Elhanan Helpman, and Kenneth Rogoff. Amsterdam: North-Holland.

Andritzky, Jochen. 2006. Sovereign Default Risk Valuation: Implications of Debt Crises and Bond Restructurings. Berlin: Springer.

Baldacci, Emanuele, Iva Petrova, Nazim Belhocine, Gabriela Dobrescu, and Samah Mazraani. 2011. “Assessing Fiscal Stress.” Working Paper no. 11/100. Washington: International Monetary Fund.

Berti, Katia, Matteo Salto, and Matthieu Lequien. 2012. “An Early-Detection Index of Fiscal Stress for EU Countries.” Economic Paper no. 475. Brussels: European Commission.

Buchheit, Lee C., Anna Gelpern, Mitu Gulati, Ugo Panizza, Beatrice Weder di Mauro, and Jeromin Zettelmeyer. 2013. "Revisiting Sovereign Bankruptcy." Washington: Brookings Institution, Committee on International Economic Policy and Reform.

Chauvin, Nicolas Depetris, and Aart Kraay. 2005. "What Has 100 Billion Dollars Worth of Debt Relief Done for Low Income Countries?” Working Paper. http:// siteresources.worldbank.org/DEC/Resources/ChauvinKraayWhatHasDebtRelief AccomplishedSept2005.pdf

Cruces, Juan J., and Christoph Trebesch. 2013. "Sovereign Defaults: The Price of Haircuts." American Economic Journal: Macroeconomics 5, no. 3: 85-117.

Dias, Daniel A., Christine Richmond, and Mark L. J. Wright. 2014. "The Stock of External Sovereign Debt: Can We Take the Data at 'Face Value'?" Journal of International Economics 94, no. 1: 1-17.

Dikhanov, Yuri. 2006. "Historical PV of Debt in Developing Countries, 1980-2002." Report no. 36153. Washington: World Bank.

Easterly, William. 2001. "Growth Implosions, Debt Explosions, and My Aunt Marilyn: Do Growth Slowdowns Cause Public Debt Crises?” Policy Research Working Paper no. 2531. Washington: World Bank.

Eaton, Jonathan, and Raquel Fernandez. 1995. "Sovereign Debt.” In Handbook of International Economics 3, edited by Gene M. Grossman and Kenneth Rogoff. Amsterdam: North-Holland.

Eaton, Jonathan, and Mark Gersovitz. 1981. "Debt with Potential Repudiation: Theoretical and Empirical Analysis." Review of Economic Studies 48, no. 2: 289-309.

EFSF (European Financial Stability Facility). 2013a. "Amendment Agreement Relating to the Loan Facility Agreement, Financial Assistance Facility Agreement, and Master Financial Assistance Facility Agreement between European Financial Stability Facility, the Portuguese Republic as Beneficiary Member State, and Banco de Portugal." Lisbon and Luxembourg.

. 2013b. "Amendment Agreement Relating to the Loan Facility Agreement, First Financial Assistance Facility Agreement, Second Financial Assistance Facility Agreement, and Master Financial Assistance Facility Agreement 
between European Financial Stability Facility, Ireland as Beneficiary Member State, and Central Bank of Ireland." Dublin and Luxembourg.

EU (European Union). 2010. "Loan Facility Agreement between the Member States Whose Currency Is the Euro and the Hellenic Republic." Brussels.

\section{Brussels.} Brussels.

. 2012a. "Amendment to the Loan Facility Agreement of February 2012." .2012b. "Amendment to the Loan Facility Agreement of December 2012." Brussels.

Eurogroup. 2012. "Eurogroup Statement on Greece.” Brussels. http://www. consilium.europa.eu/press/press-releases/2012/11/pdf/Eurogroup-statement-onGreece-27-11/

European Commission. 2010. "Report on Greek Government Deficit and Debt Statistics." Brussels.

- 2014. "Assessing Public Debt Sustainability in EU Member States: A Guide." Occasional Paper no. 200. Brussels.

—. 2015. "Greece: Request for Stability Support in the Form of an ESM Loan." Brussels.

France, Treasury Agency. 2015. Monthly Bulletin, no. 302. Paris.

German Ministry of Finance. 2014. "Request of the Federal Ministry of Finance: Grants in Favor of Greece; Technical Extension and Continuation of the Stability Support" [in German]. Berlin: German Bundestag.

House, Christopher, and Linda Tesar. 2015. "Greek Budget Realities: No Easy Option." In present volume of Brookings Papers on Economic Activity.

IMF (International Monetary Fund). 1995. "IMF Approves US\$17.8 Billion Stand-By Credit for Mexico." Press Release no. 95/10. Washington.

—. 2002. "Access Policy in Capital Account Crises." Washington.

—. 2004. "Review of Exceptional Access Policy." Washington.

- 2008. "Reform of Quota and Voice in the International Monetary Fund: Report of the Executive Board to the Board of Governors." Washington.

— . 2009. "Greece: 2009 Article IV Consultation—Staff Report; Staff Supplement; Public Information Notice on the Executive Board Discussion; and Statement by the Executive Director for Greece." Country Report no. 09/244. Washington.

— 2010a. "Greece: Staff Report on Request for Stand-By Arrangement." Country Report no. 10/110. Washington.

—. 2010b. "Minutes of Executive Board Meeting 10/45-1." Washington.

- 2011. "Greece: Fourth Review under the Stand-By Arrangement and Request for Modification and Waiver of Applicability of Performance Criteria." Country Report no. 11/175. Washington.

_ 2013a. "Sovereign Debt Restructuring: Recent Developments and Implications for the Fund's Legal and Policy Framework." Washington. 
2013b. "Staff Guidance Note for Public Debt Sustainability Analysis in Market-Access Countries." Washington.

_. 2013c. "Unification of Discount Rates Used in External Debt Analysis for Low-Income Countries.” Washington.

_. 2013d. "Staff Guidance Note on the Application of the Joint Bank-Fund Debt Sustainability Framework for Low-Income Countries." Washington.

_. 2014a. "The Fund's Lending Framework and Sovereign Debt: Preliminary Considerations." Washington.

. 2014b. "IMF Executive Board Discusses the Fund's Lending Framework and Sovereign Debt." Press Release no. 14/294. Washington.

- 2014c. Selected Decisions and Selected Documents of the International Monetary Fund, no. 37. Washington.

—. 2015a. "Greece: Debt Sustainability Analysis (Preliminary Draft)." Country Report no. 15/165. Washington.

—. 2015b. "Greece: An Update of IMF Staff's Preliminary Public Debt Sustainability Analysis." Country Report no. 15/186. Washington.

—. 2015c. "IMF Lending." Factsheet. Washington. https://www.imf.org/ external/np/exr/facts/howlend.htm

— 2016. "IMF Executive Board Approves Exceptional Access Lending Framework Reforms." Press Release no. 16/31. Washington.

Italy, Department of the Treasury. 2015. "Government Debt: Breakdown by Instrument as of July 31, 2015." Rome: Ministry of Economy and Finances.

Kaminsky, Graciela, Saul Lizondo, and Carmen M. Reinhart. 1998. "Leading Indicators of Currency Crises." IMF Staff Papers 45, no. 1: 1-48.

Kaminsky, Graciela L., and Carmen M. Reinhart. 1999. "The Twin Crises: The Causes of Banking and Balance-of-Payments Problems." American Economic Review 89, no. 3: 473-500.

Kazarian, Paul. 2015. "Greece Sovereign Debt: Asking the Right Questions." Speech given at Conference on Rethinking Sovereign Debt. Munich: CESifo.

Kraay, Aart, and Vikram Nehru. 2004. "When Is Debt Sustainable?" Policy Research Working Paper no. 3200. Washington: World Bank.

Levy Yeyati, Eduardo, and Ugo Panizza. 2011. "The Elusive Costs of Sovereign Default." Journal of Development Economics 94, no. 1: 95-105.

Panizza, Ugo, Federico Sturzenegger, and Jeromin Zettelmeyer. 2009. "The Economics and Law of Sovereign Debt and Default." Journal of Economic Literature 47, no. 3: 651-98.

Public Debt Management Agency. 2015. Hellenic Republic Public Debt Bulletin, no. 77. Athens.

Reinhart, Carmen M., and Christoph Trebesch. 2015. "The Pitfalls of External Dependence: Greece, 1829-2015.” In present volume of Brookings Papers on Economic Activity.

Sandleris, Guido. 2015. "The Costs of Sovereign Defaults: Theory and Empirical Evidence." Working Paper no. 02/2015. Buenos Aires: Torcuato di Tella University Business School, Finance Research Centre (CIF). 
Schadler, Susan. 2013. "Unsustainable Debt and the Political Economy of Lending: Constraining the IMF's Role in Sovereign Debt Crises." CIGI Paper no. 19. Waterloo, Canada: Centre for International Governance Innovation.

Schumacher, Julian, and Beatrice Weder di Mauro. 2015. "Debt Sustainability Puzzles: Implications for Greece.” London: Centre for Economic Policy Research, VoxEU. http://www.voxeu.org/article/debt-sustainability-puzzles-implicationsgreece

Serafeim, George. 2015. “Greece's Debt: Sustainable?" Harvard Business School, Case no. 115-063. Cambridge, Mass.: Harvard Business Publishing.

Tomz, Michael, and Mark L. J. Wright. 2013. "Empirical Research on Sovereign Debt and Default." Annual Review of Economics 5: 247-72.

Van Rijckeghem, Caroline, and Beatrice Weder. 2009. "Political Institutions and Debt Crises." Public Choice 138, nos. 3-4: 378-408.

World Bank. 2014. "IBRD/IDA Management's Discussion \& Analysis and Financial Statements." Annual Report. Washington.

Zettelmeyer, Jeromin, Christoph Trebesch, and Mitu Gulati. 2013. "The Greek Debt Restructuring: An Autopsy." Economic Policy 28, no. 3: 513-63. 